\title{
Children's Books, Dolls, and the Performance of Race; or, The Possibility of Children's Literature
}

\section{Citation}

Bernstein, Robin. 2011. Children's books, dolls, and the performance of race; or, the possibility of children's literature. PMLA 126(1): 160-169.

\section{Published Version}

doi:10.1632/pmla.2011.126.1.160

\section{Permanent link}

http://nrs.harvard.edu/urn-3:HUL.InstRepos:4795341

\section{Terms of Use}

This article was downloaded from Harvard University's DASH repository, and is made available under the terms and conditions applicable to Other Posted Material, as set forth at http:// nrs.harvard.edu/urn-3:HUL.InstRepos:dash.current.terms-of-use\#LAA

\section{Share Your Story}

The Harvard community has made this article openly available.

Please share how this access benefits you. Submit a story.

\section{Accessibility}




\section{Children's Books, Dolls, and the Performance of Race; or, The Possibility of Children's Literature}

\section{ROBIN BERNSTEIN}

ROBIN BERNSTEIN, assistant professor of women, gender, and sexuality and of history and literature at Harvard University, is currently a Harrington Fellow in the Department of Theatre and Dance at the University of Texas, Austin. Her book Racial Innocence: Performing American Childhood from Slavery to Civil Rights is forthcoming in 2011 from New York University Press.
IN ABOUT 1855, THREE DECADES BEFORE FRANCES HODGSON BURNETT WROTE HER FIRST BEST-SELLING CHILDREN'S BOOK, LITTLE LORD

Fauntleroy, she was a child-Frances Eliza Hodgson-and she read Harriet Beecher Stowe's Uncle Tom's Cabin. ${ }^{1}$ She found Stowe's novel, like all the stories she encountered, to be "unsatisfactory, filling her with vague, restless craving for greater completeness of form" (Burnett 44). The form the girl craved - that is, the material she believed she needed to complete the narrative-was a black doll. ${ }^{2}$ When Burnett obtained the doll, she named it Topsy and used it to "act" out the parts of the novel she found most "thrilling" (53). Casting a white doll she already owned as Little Eva, she played out ever-repeating scenes of Eva laying hands on Topsy, awakening the hardened slave girl to Christian love. Burnett also kept the Eva doll "actively employed slowly fading away and dying," and in these scenes she took on the role of Uncle Tom (57). At other times, Burnett performed the scene of Eva's death, casting the white doll as Eva and herself as "all the weeping slaves at once" (58). And at least once she designated the doll Uncle Tom and cast herself as Simon Legree. For this scenario, the girl bound the doll to a candelabra stand. "[F]urious with insensate rage," she whipped her doll (fig. 1). Throughout the whipping, the doll maintained a "cheerfully hideous" grin, which suggested to the girl that Uncle Tom was "enjoying the situation" of being "brutally lashed" $(56,55)$.

Burnett was no outlier; many nineteenth-century white children-especially but not exclusively girls-read books about slavery and then used dolls to act out scenes of racialized violence and forced labor. The memoirist Georgianna Hamlen recalled that an antebellum childhood friend, "who had been reading about Southern plantations and the negro slaves," procured six black china dolls, which she then configured as slaves to a white doll who "looked very Southern and very proud" (227). Another girl, the future British American novelist Amelia Barr, read a schoolbook that contained "a picture of a very black slave loaded with chains, toiling in the sugar

(C) 2011 BY THE MODERN LANGUAGE ASSOCIATION OF AMERICA 
At the end of the entrance hall of the house in which she lived was a tall stand for a candelabra.

It was of worked iron

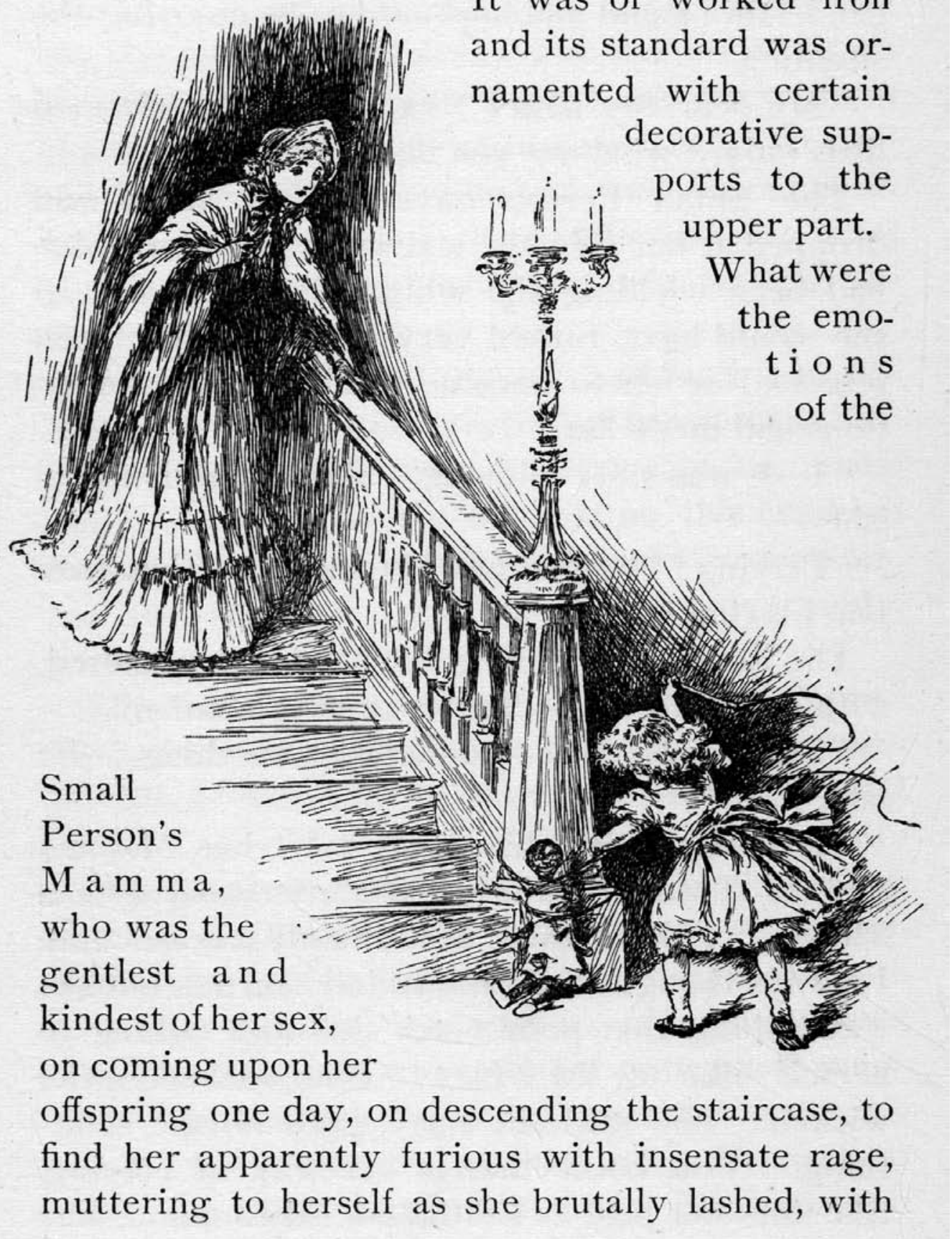

FIG. 1

Illustration by Reginald B. Birch from Frances Hodgson Burnett's The One I Knew the Best of All: A Memory of the Mind of a Child (55). Courtesy of the American Antiquarian Society. 
field, and a tall, white overseer with a whip standing near." Inspired by the picture, Barr "very soon abstracted the steel chain that held my mother's bunch of keys, loaded my negro doll with chains, [and] selected a white doll to act as overseer" ("Dolls").

These racial and racist fantasies emerged through doll play and not other means of representation, such as drawing, because for Burnett, Barr, and many other children, literature and material culture appeared to invite engagement with each other. As Burnett writes, stories in the absence of dolls were "imperfect" and dolls "seemed only things stuffed with sawdust" until "literature assisted imagination and gave them character" (44). The commercial interdependence between children's literature and material culture dates from 1744, when the British publisher and book vendor John Newbery sold A Little Pretty Pocket-Book together with balls and pincushions, and extends to the present-day American Girl series, in which books and dolls accessorize each other (Clark 1). When Newbery paired books with toys, he not only sold an extraordinary quantity of merchandise but also conceived of children as a market and children's books as a distinct literary category (Noblett). This accomplishment earned him the honorific the "father of children's literature" (Kidd 171).

Children's literature as a genre, then, emerged in crucial part through the relation between books and toys, and that connection has expanded since the eighteenth century. This magnetism with the material culture of play distinguishes children's literature from other literatures. The actions of individual book publishers and children vary infinitely, but the pairing, through play, of children's literature and toys has persisted for three centuries. Even when manufacturers do not market books and dolls in packaged combinations, many children invent their own, as Burnett did. And in recent years many works of children's literature, such as Curious George and The Cat in the Hat, which were not initially marketed with nonbook consumer items, have been commodified through products ranging from dolls to stickers to pajamas. Books and toys jumble together in children's rooms, in their beds, and in their play.

Most scholars, however, treat children's literature and material culture as separate discourses. Superb historians of play such as Karin Calvert, Howard Chudacoff, Gary Cross, and Miriam Forman-Brunell comment on literature mainly as a source or representation of ideology that concretizes in material culture. Meanwhile, leading scholars of children's literature, including U. C. Knoepflmacher, Seth Lerer, Perry Nodelman, and Maria Tatar, focus their core analyses on textual representation. Some scholars connect children's literature and toys by foregrounding their similarities: Anne Scott MacLeod, for example, reads books and toys together as meaning-making texts, while Philip Nel and Leonard Marcus historicize books and playthings as consumer products. Lois Kuznets and Sharon Marcus examine representations of dolls or doll play in literature. Even books that aim to study toys and children's literature simultaneously often draw the fields of inquiry toward each other rather than integrate them: for example, in Beverly Lyon Clark and Margaret Higonnet's foundational collection, Girls, Boys, Books, Toys: Gender in Children's Literature and Culture, most essayists consider either literature or material culture but not both. ${ }^{3}$

Either to split or to lump children's literature and material culture, however, is to erase representational play as many children's lived connection between them. For Burnett, Uncle Tom's Cabin and a black doll were not two kinds of texts (literary and visual-material, respectively), nor were they two forms of material culture. Nor did Stowe's story provide a linear narrative that the girl simply imitated. To the contrary, Burnett's practices of play connected literature and material culture without eliding differences between the two 
forms: the girl perceived an absence in a text, sought out the black doll that, in her view, filled Stowe's void, and then used the doll along with her white doll to perform scenes that she chose from among a panorama of scenarios in Uncle Tom's Cabin. Jacqueline Rose, in her 1984 field-defining book, The Case of Peter Pan; or, The Impossibility of Children's Fiction, calls children's literature "impossible" because it is the only genre that is written by one group for another group; thus, the genre imagines the category of "child" through the simultaneous describing and hailing of a category that it is in fact creating. Rose argues that children's literature creates a dynamic in which the empowered "adult comes first (author, maker, giver)" and the disempowered or even colonized "child comes after (reader, product, receiver), but ... neither of them enter the space in between" (1-2). In the past few years, scholars like Marah Gubar, Kimberley Reynolds, and David Rudd have led a reassessment of the "impossibility" of children's literature. Missing from this reassessment, however, is a consideration of how the linked acts of reading and playing disrupt Rose's paradigm. This absence obscures the role of children's agency in the formation of race. Burnett-and children like her-did not passively receive works of literature. Rather, she used dolls to reconfigure the stories she read. She entered Rose's "space in between" through play, through performance.

Representational play is performative in that it produces culture. As the Dutch historian Johan Huizinga argued in 1938, "[C]ulture arises in the form of play"; culture, including racial formation, "is played from the very beginning" $(1,46)$. Performance theorists have expanded on Huizinga's arguments to understand play as a major mode of performance in everyday life and a crucial component in the construction of race, gender, and other categories of analysis (Goffman; Bial). Burnett's play did not represent some preexisting racial or gendered essence but in- stead constructed her whiteness and girlhood through alternating performances of debased blackness and iconic whiteness in men and girls. When Burnett played weeping slaves and vicious slaveowner against her dolls, or when, as puppeteer, she ventriloquized Topsy and Eva through her dolls, she performed race and gender as complexly as did the blackface minstrels who trod the boards at that time.

When scholars tear children's literature from material culture, despite the interweaving of fiction and playthings that has grown ever denser since 1744, they create the appearance of an "impossible" top-down system in which adults produce culture and children receive it. This paradigm erases the ways in which children's play performances revise rather than only reify narratives. The stakes of this erasure become visible through a case study of the racial functions of black dolls and white children's performative doll play during the second half of the nineteenth century. ${ }^{4}$ Through these performances, nineteenth-century white children played at violence against African Americans precisely as abolition, emancipation, and then freedom were eroding American white supremacy.

Animate dolls, in literature and play, raise slavery's most foundational, disturbing, and lingering question: what is a person? As Bill Brown has observed, this question has, from the antebellum period to the present, underlain anxieties so powerfully as to constitute the "American uncanny." Uncle Tom's Cabin encapsulated and shaped these anxieties because, as Philip Fisher argues, the Emancipation Proclamation combined with the Union's military victory and "the cultural work of Uncle Tom's Cabin" to "redesign" the "boundary" between human and thing. (Stowe acknowledged this project when she originally subtitled her novel "The Man That Was a Thing" [Fisher 4, 100].) In other words, slavery legally defined some humans as things, and emancipation legally redefined all humans 
as humans. Antebellum abolitionist culture, including Uncle Tom's Cabin, laid conceptual groundwork that made this change comprehensible and therefore possible. After emancipation, however, "Lost Causers" and other white supremacists marshaled popular culture to undo this work and redesign, yet again, the boundary between human and thing. This effort appeared especially clearly in the postemancipation attempt by the Daughters of the Confederacy and other groups to freeze the imagined "faithful slave" in stone monuments (Savage; McElya; Blight).

The cultural effort to objectify and later reobjectify African Americans found rich potential in doll play and doll literature, because all stories about sentient dolls reorganize the boundary between human and thing. As Lois Kuznets observes, sentient dolls in literature "embody human anxieties about what it means to be 'real'-an independent subject or self rather than an object or other" (2). Around the time of the American Civil War, books about sentient dolls increased in popularity (Formanek-Brunell 23), and dolls in these books discuss their racial status, their duties to their owners, and even their relation with enslaved people of African descent. The doll narrator of Julia Charlotte Maitland's The Doll and Her Friends (published in 1852, the same year as Uncle Tom's Cabin) describes dolls as "a race of mere dependents; some might even call us slaves" (1). The narrator, however, pointedly informs the reader that she is "not a negro doll, with wide mouth and woolly hair" (4). In this children's book and in many others, "dollness" is itself a racial category that denotes servitude. Stowe injects anxieties about dolls and slaves, things and people, into Uncle Tom's Cabin by likening Topsy to a doll with eyes as "glittering as glass beads" (206). She is careful, however, to identify Topsy repeatedly as an "abused child" (209), even the abused child, as Richard Brodhead argues (85). When Eva converts Topsy, the enslaved girl's formerly beadlike eyes become "overcast with tears" (245); thus, Topsy's conversion alters the precise organ that previously constituted the character's doll-likeness. Stowe configures Topsy's conversion as one from superficial doll-likeness caused by slavery's pathology to the realization of Topsy's Christian and human potential; she thereby delivers one of her sharpest arguments against slavery (84-86).

When Burnett read Uncle Tom's Cabin, however, she was not filled with the impulse to engage in abolitionist activism or even to "feel right" but instead wanted to reconstitute Topsy in doll form - that is, to reverse the trajectory that Stowe wrote for Topsy. Thus, Burnett resisted Stowe's narrative even as she enacted it. Burnett behaved not only from an individual, psychological urge but also, crucially, in response to two cultural prompts: Stowe's narrative and the doll's color and tough physical composition.

Nineteenth-century doll manufacturers invited enactments of racial violence when they made black dolls of materials, especially rubber and cloth, that could withstand rough usage that would destroy dolls of ceramic or wax. Patent applications and advertisements often described soft black dolls as prompts toward violent play. In 1893-94, for example, the Arnold Print Works of Massachusetts advertised a black doll alternately called "Topsy" and "Pickaninny": "What child in America does not at some time want a cloth 'Nigger' dollie-one that can be petted or thrown about without harm to the doll or anything that it comes in contact with[?] 'Pickaninny' fills all the requirements” (550). The advertisement claimed that the doll, identified by a racial epithet, could and should be "thrown about" because it was black and made of cloth and that this abusability constituted desirability. For the Massachusetts manufacturer that named its doll "Topsy" and for Burnett, soft black dolls combined with the narrative of Uncle Tom's Cabin to script performances of violent play. 
The term script does not refer to compulsory behavior but instead describes a set of invitations or prompts that by definition remain open to resistance and revision. Like theatrical practitioners, I understand a script as a dynamic substance that deeply influences but does not entirely determine live performances, which constantly change according to agents' visions, impulses, and accidents. Items of material culture "script" in much the same sense that literary texts "mean": neither a thing nor a poem (for example) is conscious or agential, but a thing can invite behaviors that its maker both did and did not envision and a poem may produce meanings that both include and exceed a poet's intentions. To describe elements of material culture as "scripting" actions is to suggest not that a thing possesses agency or that people lack agency but, instead, that agency and intention emerge through everyday engagement with the stuff of our lives. In my forthcoming book, I develop a method for reading the scripts coproduced through literature and material culture; I use archival evidence to determine the documented, probable, and possible uses of a category of object such as a doll. (See also Bernstein, "Dances.") This horizon of known and possible uses then informs a close reading of an individual artifact. The operative questions are, What historically located behaviors did this artifact invite, and what actions did it discourage? The goal is not to determine what any individual did with an artifact but rather to understand how a nonagential artifact, in its historical context, prompted or invited-scripted-actions of people who were agential and often resistant. The act of scripting, that issuing of a culturally specific invitation, was itself a historical event-one that can be recovered and analyzed as a fresh source of evidence.

Toni Morrison fictively describes the process of scripting and its racial ramifications in The Bluest Eye, set in 1941: her narrator, a black girl named Claudia, recalls being given a white baby doll and wondering, "What was
I supposed to do with it? Pretend I was its mother?" However, Claudia read "[p]icture books" that were "full of little girls sleeping with their dolls"- that is, white girls and white dolls. From these books she "learned quickly" that she was "expected" to "rock [the doll], fabricate storied situations around it, even sleep with it" (20). The narratives in Claudia's picture books combined with the materiality of the doll-its blond hair and white skin-to tell Claudia what she was "supposed to do"; that is, children's literature together with the doll prompted tender bodily actions, and these actions interpellated Claudia into a racist ideology that the novel attacks.

Like the fictional Claudia, historical children of the nineteenth century absorbed prompts toward tender play with white dolls, but they also received the violent scripts coproduced by black dolls like the Arnold Print Works' Topsy and by the widespread, repetitious works of children's literature in which black dolls underwent whipping, flogging, beating, drowning, shooting, burning, decapitation, or destruction from overwork (Jimmy; Trew; Aunt Fanny; E. L. E.; Optic). Certainly, girls in literature and in life abused white dolls (Marcus 159-63; Formanek-Brunell 24-32), but novels singled out black dolls for especial viciousness and racially specific forms of violence, such as hanging. D. P. Sanford's Frisk and His Flock provides one example. In this 1875 novel, a white girl named Eva (a name that invokes Stowe's novel) hangs a black doll "for a punish"-a spectacle that causes other white children to laugh (110 [fig. 2]).

Many white children performed the violence that black dolls and children's literature coscripted: they whipped, beat, and hung black dolls with regularity and ritualistic ferocity. In the magazine Babyhood in 1887, for example, a mother told how her daughter's black rag doll had endured a "gash in her throat" (English 264). A decade later, the psychologists G. Stanley Hall and A. Caswell Ellis observed white children in Worcester, 


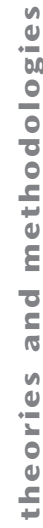

Massachusetts, burning black dolls and using them to stage slave auctions $(30,34)$. And in 1898, when a Minneapolis newspaper invited children to write letters describing their play with toys, seven of the forty published letters focused on black dolls, and most of them reported violence. A girl named Alice Leland stated that she had "burned to death" a black doll, while $\mathrm{Wm}$. Scholtz reported that he enjoyed pinching his "little black rubber

FIG. 2

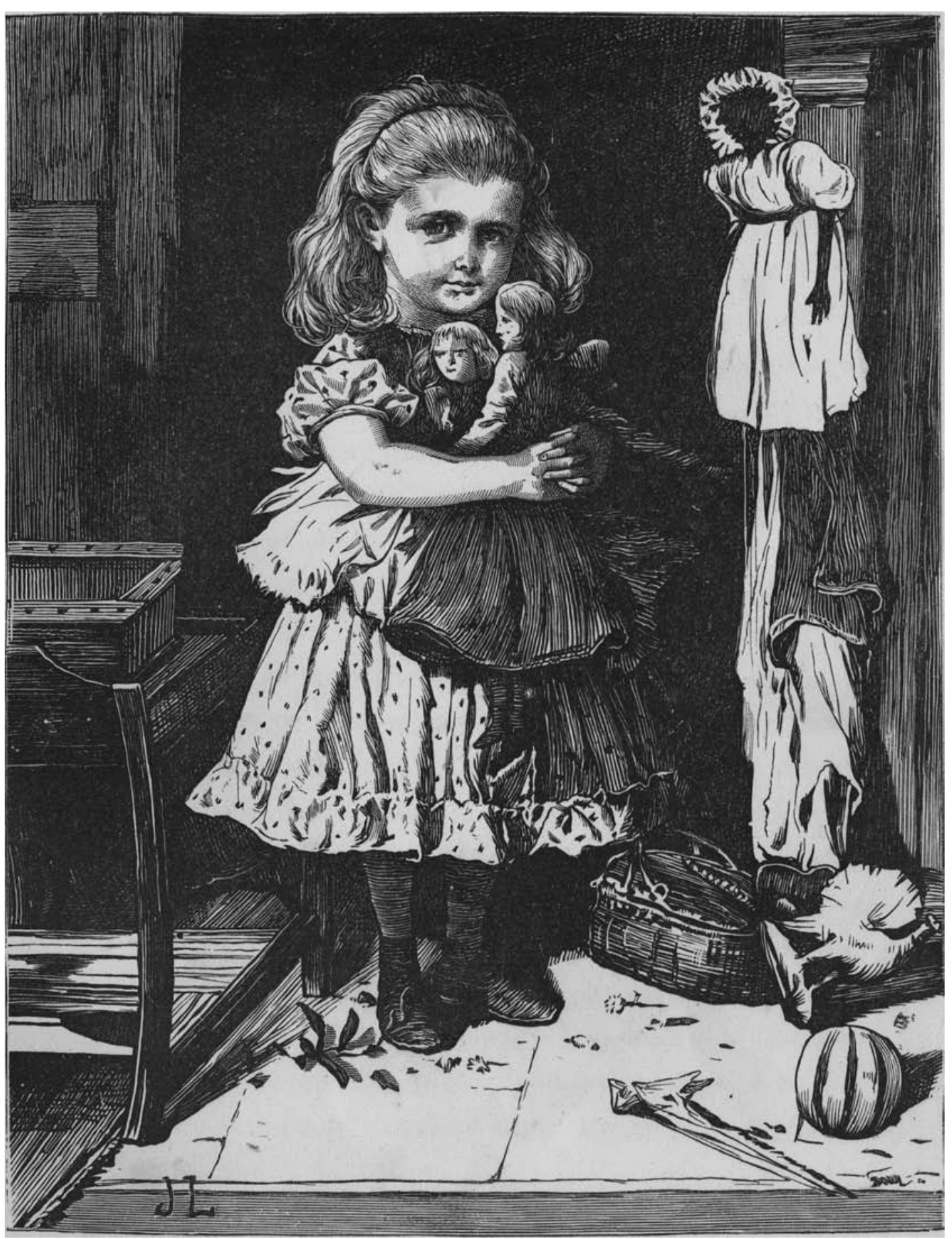

"How the children laughed! Eva had hung her old black doll, Dinah, against a beam, 'for a punish' as she said." From D. P. Sanford's Frisk and His Flock (110). Elizabeth Nesbitt Room, Information Sciences Library, University Library System, University of Pittsburgh. 
doll named Tom" and that he allowed a cat to "bite Tom's toes and pull his hair." He declared that his Tom doll, like Burnett's rubber doll of the same name, "never complained." Harry Cass enjoyed violence with his black doll: "Sometimes I would play I was hanging him" (“Toys" 1, 6-7).

Harry Cass performed a lynching but probably never witnessed one: no African Americans were hung-legally or by a mob-in Minnesota during the seventh-grader's lifetime (Bessler 104-05). And the Worcester children whom Hall and Ellis observed playing at "slave selling" in 1897 could not have witnessed slave auctions. These children-like Burnett, Georgianna Hamlen's friend, and Amelia Barrperformed in response to narratives they read, saw, or heard and to the materiality of dolls. Perhaps the slave-selling children of Worcester had read Uncle Tom's Cabin. Cass, who also named his doll Tom, may have read Stowe's novel, and perhaps he read Frisk and His Flock or one of the many other stories in which white children hung black dolls. And he very likely observed the play of other children, including that of his Minneapolis neighbors who cheerfully reported burning and otherwise destroying black dolls.

Literature and material culture, I have argued, coscripted nineteenth-century practices of play, and white children like Burnett enacted-and thus revised-the scripts. This process of reinvention, of repetition with differences, was collective. Nineteenth-century doll play was never private; representational play occurred in the home and also outside, where it was witnessed by adults and, more important, other children. Children and former children described their play in periodicals and books, further transmitting practices from child to child. Burnett took cues from Stowe's novel and a doll, but then she published accounts of her play and thus coscripted other children's behaviors: in 1888, when she was publicizing Little Lord
Fauntleroy, a girl approached her to say she had read about Burnett's whipping of her black doll and had been inspired to play in similar ways with her own black doll ("Little Lord Fauntleroy" 17).

Since the eighteenth century, children's play has increasingly connected children's literature with material culture; today children's play, literature, and material culture are conjoined. Many observers decry these connections as the commercialization and dilution of literature. But it is precisely these connections that deliver children's literature beyond the paradigm of "impossibility." In the triangulation of play, literature, and material culture, the three categories of cultural actors are children, authors, and those who manufacture and sell playthings. In other words, children are coproducers in the play-book-toy formation from which children's literature is now inextricable. Some scholars criticize the commodification of children's literary characters in everything from dolls to pajamas to keychains to sneakers, but as children play with, dream in, and unlock doors with the material interdependents of children's literature-as they literally walk in characters' shoes-they alter the landscape of children's literature, as Eliza Hodgson Burnett and Harry Cass did when they recast Topsy and Uncle Tom as things. Pace Rose, children not only receive literature, they receive the coscripts of narratives and material culture and then collectively forge a third prompt: play itself. The three prompts then entangle to script future play. The scripts that children cocreate with authors and toymakers are inseparable from children's literature and are therefore a functional part of it. Performative play makes children's literature possible-all too possible, it turns out. The possibility of children's literature forces us to look anew at nineteenthcentury white children and see not racist culture's reflectors but its coproducers. 


\section{NOTES}

I thank Colleen S. Boggs, Julie Buckler, Caroline Levander, Linda Schlossberg, and especially Ellen Gruber Garvey.

1. Barbara Hochman reads Uncle Tom's Cabin as children's literature. Stowe's novel was widely read by or to children, starting with Stowe's own, to whom the author read her first draft (C. Stowe 148-49). On children's ability to define a work as children's literature by reading it, see Hunt 2-4. Marah Gubar argues in this issue of PMLA that defining children's literature as anything young people read is overly broad but that including children's acts of reading among qualities that constitute the "family resemblance" of children's literature grants the suppleness that the field requires.

2. Black doll is the term that people of diverse races used most consistently throughout the nineteenth and twentieth centuries to identify dolls that represent people of African descent.

3. Karen Sánchez-Eppler and Gillian Brown are among the few scholars who analyze literature, material culture, and historical children's practices in complex relation with one another.

4. For analysis of the construction of gender and sexuality through literary representations of doll play, see Marcus 149-66. For analysis of African American children's practices with dolls, see Bernstein, Racial Innocence. On representations of Japanese dolls, see Shoaf.

\section{Works CiTED}

Arnold Print Works. Advertisement. Youth's Companion 26 Oct. 1893: 550. American Periodicals Series Online. Web. 29 June 2010.

Aunt Fanny [France Elizabeth Barrow]. The Children's Charity Bazaar. Edinburgh: Edmonston, 1870. Print.

Bernstein, Robin. "Dances with Things: Material Culture and the Performance of Race." Social Text 101 (2009): 67-94. Print.

- Racial Innocence: Performing American Childhood from Slavery to Civil Rights. New York: New York UP, forthcoming.

Bessler, John D. Legacy of Violence: Lynch Mobs and Executions in Minnesota. Minneapolis: U of Minnesota P, 2003. Print.

Bial, Henry. "Play." The Performance Studies Reader. Ed. Bial. 2nd ed. New York: Routledge, 2007. 115-16. Print.

Blight, David W. Race and Reunion: The Civil War in American Memory. Cambridge: Belknap-Harvard UP, 2001. Print.

Brodhead, Richard H. "Sparing the Rod: Discipline and Fiction in Antebellum America." Representations 21 (1988): 67-96. Print.

Brown, Bill. "Reification, Reanimation, and the American Uncanny.” Critical Inquiry 32.2 (2006): 175-207. Print.
Brown, Gillian. "Child's Play.” Differences 11.3 (19992000): 76-106. Print.

Burnett, Frances Hodgson. The One I Knew the Best of All: A Memory of the Mind of a Child. New York: Scribner's, 1893. Print.

Clark, Beverly Lyon. Introduction. Clark and Higonnet 1-8.

Clark, Beverly Lyon, and Margaret R. Higonnet, eds. Girls, Boys, Books, Toys: Gender in Children's Literature and Culture. Baltimore: Johns Hopkins UP, 1999. Print.

"Dolls of Famous Women: Miss Mary Wilkins, Miss Susan B. Anthony, Mrs. Kate Douglas Wiggin and Others Had Them." Portland Oregonian 16 Apr. 1899: 17. Nineteenth Century U.S. Newspapers. Web. 29 June 2010.

E. L. E. “Topsy.” Youth's Companion 8 May 1879: 159. American Periodicals Series Online. Web. 29 June 2010.

English, Margaret. "Home-made Rag Doll." Babyhood: A Monthly Magazine for Mothers Devoted to the Care of Infants and Young Children, and the General Interests of the Nursery July 1887: 264. Google Books. Web. 29 June 2010.

Fisher, Philip. Hard Facts: Setting and Form in the American Novel. New York: Oxford UP, 1987. Print.

Formanek-Brunell [Forman-Brunell], Miriam. Made to Play House: Dolls and the Commercialization of American Girlhood, 1830-1930. New Haven: Yale UP, 1993. Print.

Goffman, Erving. The Presentation of Self in Everyday Life. Garden City: Anchor-Doubleday, 1959. Print.

Grandmother Trew. "Sweet-Water." Youth's Companion 9 Sept. 1869: 284. American Periodicals Series Online. Web. 29 June 2010.

Hall, G. Stanley, and A. Caswell Ellis. A Study of Dolls. New York: Kellogg, 1897. Print.

Hamlen, Georgianna. Chats: "Now Talked of This and Then of That." Boston: Lee, 1885. Google Books. Web. 29 June 2010.

Hochman, Barbara. Uncle Tom's Cabin and the Reading Revolution: Race, Childhood, and Fiction-Reading, 18511911. Amherst: U of Massachusetts $P$, forthcoming.

Huizinga, Johan. Homo Ludens: A Study of the PlayElement in Culture. Trans. Huizinga. New York: Roy, 1950. Print.

Hunt, Peter. Children's Literature: An Anthology, 18011902. Malden: Blackwell, 2001. Print.

Jimmy: Scenes from the Life of a Black Doll. Told by Himself to J. G. Sowerby. London: Routledge, 1888. Print.

Kidd, Kenneth B. "Prizing Children's Literature: The Case of Newbery Gold." Children's Literature 35 (2007): 166-90. Print.

Kuznets, Lois. When Toys Come Alive: Narratives of Animation, Metamorphosis, and Development. New Haven: Yale UP, 1994. Print.

"Little Lord Fauntleroy: A Pleasant Chat with the Gifted Author of a Children's Classic." Daily Inter Ocean 
[Chicago] 4 Nov. 1888: 17. Nineteenth Century U.S. Newspapers. Web. 29 June 2010.

Maitland, Julia Charlotte. The Doll and Her Friends; or, Memoirs of the Lady Seraphina. London: Grant, 1852. Print.

Marcus, Sharon. Between Women: Friendship, Desire, and Marriage in Victorian England. Princeton: Princeton UP, 2007. Print.

McElya, Micki. Clinging to Mammy: The Faithful Slave in Twentieth-Century America. Cambridge: Harvard UP, 2007. Print.

Morrison, Toni. The Bluest Eye. New York: Pocket-Simon, 1970. Print.

Noblett, William. "John Newbery: Publisher Extraordinary." Only Connect: Readings on Children's Literature. Ed. Sheila A. Egoff, G. T. Stubbs, and L. F. Ashley. New York: Oxford UP, 1980. 28-38. Print.

Optic, Oliver. Dolly and I. Boston: Lee, 1863. Print.

Rose, Jacqueline. The Case of Peter Pan; or, The Impossibility of Children's Fiction. 1984. Philadelphia: U of Pennsylvania P, 1993. Print.
Sánchez-Eppler, Karen. Dependent States: The Child's Part in Nineteenth-Century American Culture. Chicago: U of Chicago P, 2005. Print.

Sanford, D. P. Frisk and His Flock. 1875. New York: Dutton, 1877. Print.

Savage, Kirk. Standing Soldiers, Kneeling Slaves: Race, War, and Monument in Nineteenth-Century America. Princeton: Princeton UP, 1997. Print.

Shoaf, Judy. "Queer Dress and Biased Eyes: The Japanese Doll on the Western Toyshelf." Journal of Popular Culture 43.1 (2010): 176-94. Academic Search Premier. Web. 31 June 2010.

Stowe, Charles Edward. The Life of Harriet Beecher Stowe. Boston: Houghton, 1890. Uncle Tom's Cabin and American Culture. Web. 29 June 2010.

Stowe, Harriet Beecher. Uncle Tom's Cabin; or, Life among the Lowly. 1852. Ed. Elizabeth Ammons. New York: Norton, 1994. Print.

“Toys That Made Childhood Sweet." Minneapolis Journal 17 Dec. 1898, supplement: 1+. America's Historical Newspapers. Web. 29 June 2010. 